\title{
Contaminants in Agriculture: Threat to Soil Health and Productivity
}

\author{
Abid Ali Ansari ${ }^{1 *}$, M Naeem ${ }^{2}$ and Sarvajeet Singh Gill ${ }^{3}$ \\ ${ }^{1}$ Department of Biology, University of Tabuk, Saudi Arabia \\ ${ }^{2}$ Department of Botany, Aligarh Muslim University, India \\ ${ }^{3}$ Stress Physiology and Molecular Biology Laboratory, Maharshi Dayanand University, India
}

Submission: April 27, 2018; Published: May 11, 2018

*Corresponding author: Abid Ali Ansari, Department of Biology, Faculty of Science, University of Tabuk, Saudi Arabia, Email: aansari@ut.edu.sa

Abstract

Agricultural, horticultural and other industrial activities are major causes of contaminating the soils, sediments and waters in adjacent environments. Agricultural contaminants include organic and inorganic fertilizers, pesticides, herbicides and insecticides; organic matter such as animal wastes and decaying plant material; irrigation residues like salts and trace metals; and microorganisms. Innovative management strategies are required to maximize the benefits from the agricultural inputs, while minimizing their off-site migration and impact on the receiving environments.

Keywords: Contaminated soils; Soil productivity; Management strategies.

\section{Mini Review}

Soil is the important resource for various basic needs of humans and essential for our sustenance. But the soil is continuously losing its quality parameters at the cost of development and industrialization. Microorganisms, minerals and nutrients directly influence the agricultural developments and economy. Lack of awareness and poor uptake of technologies is result into nutrient deficiencies and deterioration of soil, low productivity and economic losses. However, many indices and indicators for soil quality have been proposed but still some more parameters to evaluate sustainable and unsustainable soils are urgently required [1].

Therefore, intense research on following prospective is a need of hour to embark upon the challenging issues of contaminants in agriculture rising day by day that are being involved in current scenario:

a. Environmental awareness on contaminants in agriculture

b. Types of contaminants their sources and impacts on agriculture such as:

I. Heavy metals

II. Pesticides, herbicides and insecticides

III. Fertilizers (organic \& inorganic)

\section{Pathogens}

V. Nutrients

VI. Animal Wastes

VII. Nano-contaminants

VIII. Management strategies for agricultural contaminants including:

IX. Planning and engineered applications

X. Utilization of agricultural wastes

XI. Bioremediation applications

Approaches and Challenges for Crop Protection and Production under Contaminated Soils

Over the past few decades, the increase in population and advances made in farming technology has increased the demand for crops and livestock. The environmental impact of agriculture is based on the wide variety of agricultural practices employed around the world. An estimated 2.2 million people are at risk due to exposure from agricultural contaminants, with the majority of this population being residing in developing nations. The degradation of water, air, and soil quality by nutrients originating from agriculture is an international environmental issue. Some of the environmental issues that are related to agriculture are 
climate change, deforestation, genetic engineering, irrigation problems, pollutants, soil degradation, and waste. Mostly it is caused by industrial activity, agricultural chemicals, or improper disposal of wastes. Undoubtedly, soil contaminants can have significant deleterious consequences for ecological ecosystem. Soil contaminant enters the food chain through producers/green plants at the first trophic level and may affect the structure of an ecosystem. In the pursuit of meeting increasing demands for food and fiber, modernization of agriculture has involved a rapid increase in the use of agro-chemicals (fertilizers and pesticides) and its mechanization. This has occurred without any serious regard to the adverse environmental consequences [2-4].

Efficient management strategies for the agricultural contaminants pave the way to combat the challenges to improve the production of agricultural crops. Application of targeted, sufficient, and balanced quantities of fertilizers will be necessary for high yields without polluting the environment. At the same time, every effort should be made to improve the availability and use of secondary- and micro-nutrients, organic fertilizers, and soil-conservation practices to develop over all crop production in an efficient and environmentally generous manner, without sacrificing soil health and/or productivity. Agriculturists should focus more to increase agricultural productivity while decreasing its environmental footprint. Plants and its waste will in the near future be a chief source for the production of energy, biofuels and biopolymers, replacing the use of fossil fuels as feedstock. However, new technologies must be applied within systems that are both economically and environmentally sustainable [5].

\section{Conclusion}

Agricultural soil contamination and its consequences results into biodiversity loss and posing major threats to soil health and its productivity. Strong actions need to be taken for the sustenance of soil quality. Environmental education on soil technologies, toxicology, contamination, management, protection and conservation is one of the important measures. Some practical and cost-effective measures should be developed to reduce uptake of contaminants by agricultural crops from contaminated soils.

\section{References}

1. Chauhan A, Mittu B (2015) Soil Health - An Issue of Concern for Environment and Agriculture. J Bioremed Biodeg 6: 286.

2. Andrews SS, Karlen DL, Cambardella CA (2004) The soil management assessment framework: A quantitative soil quality evaluation method. Soil Science Society of America Journal 68: 1945-1962.

3. Bastida F, Moreno JL, Hernandez T, Garcia C (2006) Microbiological degradation index of soils in a semiarid climate. Soil Biology and Biochemistry 38(12): 3463-3473.

4. Breure AM, Mulder CH, Rutgers M, Schouten T, De Zwart D, et al. (2004) A biological indicator for soil quality. In: proceedings from an OECD expert meeting Rome, Italy, March 2003: agricultural impacts on soil erosion and soil biodiversity: Developing indicators for policy analysis, pp. $485-494$

5. Fries W, Fried J, Platzer K, Horak O, Gerzabek MH (2006) Remediation of contaminated agricultural soils near a former $\mathrm{Pb} / \mathrm{Zn}$ smelter in Austria: Batch, pot and field experiments. Environmental Pollution 144 (1): 40-50.
Your next submission with Juniper Publishers will reach you the below assets

- Quality Editorial service

- Swift Peer Review

- Reprints availability

- E-prints Service

- Manuscript Podcast for convenient understanding

- Global attainment for your research

- Manuscript accessibility in different formats

( Pdf, E-pub, Full Text, Audio)

- Unceasing customer service

Track the below URL for one-step submission https://juniperpublishers.com/online-submission.php 